\title{
СТРУКТУРА МОРАЛЬНОЇ САМОСВІДОМОСТІ ОСОБИСТОСТІ
}

\author{
Людмила Котлова \\ кандидат психологічних наук, доцент кафедри психології розвитку \\ та консультування \\ Житомирський державний університет імені Івана Франка \\ 10008, Україна, м. Житомир, вул. Велика Бердичівська, 40 \\ kotlova.lo@i.ua, https://orcid.org/0000-0003-2994-6724
}

\section{Анотація}

Стаття присвячена теоретичному аналізу підходів щодо розуміння структури моральної самосвідомості особистості. Дослідження спрямоване на виокремлення психологічних особливостей, структури та механізмів моральної самосвідомості особистості. Основними завданнями стали психологічний аналіз та на його основі узагальнення особливостей структури моральної самосвідомості.

Морально зрілій особистості притаманний високий рівень моральної свідомості та самосвідомості, що проявляється в стійкості переконань і вірності своїм ідеалам, у розумінні та оцінці інших і себе, в самостійності та правильності прийнятих рішень, послідовності добровільних учинків, моральній надійності, здатності протистояти внутрішнім поривам, вмінні враховувати зовнішні обставини. Моральна самосвідомість розглядається як специфічна форма моральної свідомості, усвідомлення себе, своїх моральних цінностей, ставлень, якостей, потенційних можливостей, учинків, їх мотивів і наслідків, регулювання власної поведінки та моральне самовдосконалення.

Виділено два рівні моральної самосвідомості: на першому рівні відбувається порівняння «Я» іншої людини, оцінювання ії якостей, а потім ці якості переносяться на себе; на другому рівні відбувається співвіднесення знань про себе в процесі аутокомунікації, тобто в межах «Я і Я». Людина вже оперує готовими, сформованими знаннями про себе. На цьому рівні вона співвідносить свою поведінку з тією мотивацією, яку реалізує.

Моральна самосвідомість може мати трьохкомпонентну структуру: афективний (емоційний), когнітивний, поведінковий (регулятивний) компоненти або чотирьохкомпонентну: когнітивний, світоглядний, поведінковий, емоційний. Основними змістовими характеристиками когнітивного компоненту моральної самосвідомості $\epsilon$ моральні знання, переконання, моральна рефлексія. Емоційно-ціннісна складова моральної самосвідомості представлена моральними цінностями та моральними почуттями. Поведінковий компонент - моральною саморегуляцією.

Моральна самосвідомість - це не лише осмислення певних проблем та обставин життя 3 точки зору моральних цінностей, що їх визнає конкретна людина, це й власна іiі самооцінка і спроба розібратися у справедливості й обгрунтованості моральних засад, якими вона керується.

Ключові слова: моральна самосвідомість, афективний компонент, емоційний компонент, когнітивний компонент, поведінковий компонент, світоглядний компонент.

\section{Вступ}

У період соціально-економічних і політичних змін актуальним постає питання виховання в особистості таких універсальних моральних цінностей, як совість, свобода, відповідальність, чесність, гідність, патріотизм, самодостатність, від яких залежатиме розвиток, упевненість у собі, психічне здоров'я людини, яка здатна розбудовувати державу і відстоювати національні та власні інтереси. 
Морально зрілій особистості притаманний високий рівень моральної свідомості та самосвідомості, що проявляється в стійкості переконань і вірності своїм ідеалам, у розумінні й оцінці інших і себе, в самостійності та правильності прийнятих рішень, послідовності добровільних учинків, моральній надійності, здатності протистояти внутрішнім поривам, умінні враховувати зовнішні обставини. Особливо потребує уваги становлення моральної самосвідомості в період євроінтеграції нашої держави, оскільки сучасне європейське суспільство висуває до нас низку вимог, а саме: формування чесної, толерантної, відповідальної, здатної до саморозвитку, моральної особистості.

Таким чином, активізація та стимулювання розвитку моральної самосвідомості громадян розглядається сьогодні як один із пріоритетних напрямів покращення ефективності формування соціальних компетентностей особистості для подолання життєвих труднощів.

Варто зазначити, що події, які відбуваються в нашій державі останні п’ять років, неоднозначно вплинули на поведінку громадян. 3 одного боку, ми можемо спостерігати зростання патріотизму, національної самоідентичності, цінності миру, життя, волонтерства, а 3 іншого - збільшення шахрайства, корупції, крадіжок, заробітку будьякими нечесними шляхами, зростання бідності, аморальності вчинків задля виживання тощо.

Варто зазначити, що в останні десятиліття зросла активність українських учених щодо вивчення структури моральної самосвідомості (Булах, 2016; Зимянський, 2009; Павелків, 2005), проблеми розвитку та виховання моральної свідомості та самосвідомості (Алексєєва, 2006; Бех, 2012; Бондаревська, 2007; Васянович, 2003; Савчин, 2005), що вказує на актуальність та недостатню вирішеність цієї проблеми.

У своїх дослідження зарубіжні науковці (Krettenauer, 2020; Walker, 2020) вказують на те, що особливо у молоді викривлюється моральна мотивація, підвищується правовий і моральний нігілізм, почуття вседозволеності та безнаказаності, втрата життєвого оптимізму. У зв'язку з цим W. Althof, M. Berkowitz, H. Han наголошують на важливому значенні сім’ї у вихованні моральної самосвідомості особистості (Althof \& Berkowitz, 2006; Han, 2014).

На нашу думку, вирішення означених проблем можливе за умови психологічного i педагогічного супроводу розвитку моральної самосвідомості на різних етапах онтогенезу.

Основна мета нашого дослідження спрямована на теоретичне виокремлення психологічних особливостей, структури та механізмів моральної самосвідомості особистості. Основними завданнями стали психологічний аналіз та узагальнення на його основі особливостей структури моральної самосвідомості.

\section{Методи дослідження}

Методи аналізу, синтезу та узагальнення будуть застосовані щодо наукових праць, у яких розглянуто психологічні особливості та структуру моральної самосвідомості особистості, виокремлено механізми її розвитку.

\section{Результати та дискусії}

Перш ніж розглядати психологічні особливості моральної самосвідомості, необхідно визначити такі взаємопов'язані поняття, як «свідомість», «самосвідомість» і «моральна свідомість».

У психології свідомість традиційно тлумачать як «найвищий рівень психічного відображення навколишньої дійсності, що розвинувся у людини як суспільної істоти внаслідок оволодіння мовою і спільною діяльністю з іншими людьми» (Степанов, 2006: 247). Тобто, це властивість людського мозку, завдяки чому людина ставить перед собою мету, регулює поведінку, впливає на інших. 
Варто зауважити, що наявність процесу усвідомлення дійсності забезпечує регуляцію життєдіяльності особистості, координацію поведінки у відповідності 3 потребами оточуючих та об'єктивними умовами. Ядром свідомості є схильність до рефлексії, без якої неможливий розвиток самосвідомості. Самосвідомість розглядається нами як система психічних механізмів, яка пов'язана з усвідомленням людиною себе самої як особистості, своєї діяльності як члена суспільства, стосунків з іншими людьми, рис характеру, здібностей, власних дій та вчинків, їх мотивів, цілей, моральних, фізичних властивостей (Синявський \& Сергєєнкова, 2007).

Як зазначає I. Кон, у структуру самосвідомості входять самопізнання, емоційноціннісне ставлення до себе і поведінково-вольова сфера як саморегуляція. Центральним структурним компонентом є самооцінка (Кон, 1984).

Однією зі сторін свідомості є моральна свідомість - це не лише осмислення певних проблем та обставин життя з точки зору моральних цінностей, що їх визнає особистість, а й власна самооцінка цих цінностей.

Як вказує Р. Павелків, моральна свідомість - це особливий конструкт психіки, що забезпечує розуміння і прийняття моральних законів та організацію людиною власної поведінки відповідно до них (Павелків, 2005).

Варто відзначити погляди Є. Бондаревської, яка зазначає, що моральна свідомість особистості - це процес відображення індивідуальною свідомістю морального аспекту суспільних подій та актів поведінки, в результаті яких здійснюється їх моральна оцінка. Робиться вибір та регуляція діяльності і поведінки у відповідності 3 інтересами суспільства, які виявляються у нормах суспільної моралі (Бондаревська, 2007). На думку Ю. Алєксєєвої, моральна свідомість є найважливішою складовою свідомості суб'єкта, його моральних взаємин. Вона містить у собі як пізнання сутності моралі, так i загальнолюдських норм і правил поведінки, а, отже, систему ставлень людини до цих норм і правил (Алєксєєва, 2006).

На основі аналізу наукових джерел (Боришевський, 1985; Братусь, 1994) можна виділити два блоки у структурі моральної свідомості: 1) об'єктивний (описовоконстатуючий), що базується на морально-гностичній діяльності індивіда, який спрямований на пізнання сутності моралі, зокрема, на утворення моральних знань, що виступають у формі моральних уявлень, понять і суджень; 2) суб' єктивний, заснований на формуванні ставлень особистості до соціальних норм і правил, що виступають у формі таких структурних елементів моральної свідомості, як моральні переконання, погляди, ідеали і світогляд.

За своєю сутністю моральна свідомість $є$ необхідною умовою та наслідком соціалізації особистості. Жоден акт людської поведінки (дія, вчинок), жоден акт взаємодій (взаємини, комунікація, співдія), як зазначає А. Зимянський, не могли б отримати морального виміру, якби особистість не була здатна усвідомлювати їх внутрішню проблематику, співвідносити їх із власними уявленнями про добро та зло, належне i справедливе, з «голосом» власного розуміння (Зимянський, 2009). Відтак у структурі моральної свідомості генетично виникає моральна самосвідомість.

У психології існує багато підходів до розуміння сутності моральної самосвідомості. Так, В.Столін моральну самосвідомість розглядає як зіткнення двох мотивів, що утворюють різні та суперечливі смисли одного і того ж. Тут мають вплив ідеали, соціальні норми, цінності, власні особистісні якості (Столін, 1983). Згодом можемо побачити продовження цього підходу у працях I. Чеснокової, де виділяються два рівні самосвідомості: на першому відбувається порівняння «Я» іншої людини, оцінювання іiі якостей, а потім ці якості переносяться на себе; на другому рівні співвідносяться знання про себе в процесі аутокомунікації, тобто в межах «Я і Я». Людина вже оперує готовими, сформованими знаннями про себе. На цьому рівні вона співвідносить свою поведінку 3 тією мотивацією, яку реалізує (Чеснокова, 1997). 
Що стосується компонентів моральної самосвідомості, то тут одні вчені надають перевагу когнітивному компоненту (Боришевський, 1985; Павелків, 2005; Титаренко, 1974), інші наголошують на емоційно-ціннісному складнику (Савчин, 2005; Якобсон, 1985), а частина робить акцент на важливості самоконтролю, моральної саморегуляції та дій як показника поведінкової складової моральної самосвідомості (Якобсон, 1981). Значна кількість праць присвячена дослідженню моральних почуттів на різних вікових етапах (Клочек, 2009; Флоренська, 2001).

Основними змістовими характеристиками когнітивного компоненту моральної самосвідомості є моральні знання, переконання, моральна рефлексія. Процес формування моральних знань, як указує М. Боришевський (1985), в індивіда має певні етапи: від елементарних відомостей про моральні поняття до уміння застосовувати отримані знання на практиці в житті. Рівень розвитку якісних характеристик моральних знань впливає на процес переходу моральних знань у моральні переконання: їх обсяг, оперативність, усвідомленість і міцність.

Моральні переконання - внутрішньоприйняті особистістю, пережиті та узагальнені моральні принципи, норми поведінки. На основі моральних переконань реалізується моральна спрямованість особистості. Традиційно вчені зазначають, що моральні переконання формуються в процесі виховання, розвитку та соціалізації особистості (Зимянський, 2009; Павелків, 2005). Однак нещодавні дослідження психологів із Університету штату Пенсільванія вказують на те, що схильність до певних моральних переконань і принципів може передаватися у спадок. Їхнє дослідження $є$ лонгітюдом, тривалістю в 13 років, за результатами було встановлено, що існує взаємозв'язок між позитивним вихованням батьків і високими показниками відповідальності у свідомості підлітків і наявна кореляція між показниками братів і сестер, які пов'язані між собою спорідненістю. У висновках зазначається, що моральні переконання особистості можуть залежати як від спадкових факторів, так і від зовнішніх. На думку Дж. Нідехайзер, «більшість припускає, що характер і моральні переконання дітей формуються виключно під впливом виховання. Однак ця інформація говорить про те, що є і генетичний вплив. Це не означає, що у свідомих батьків обов'язково буде свідома дитина, але це значить, що діти успадковують схильність поводити себе певним чином» (Нідехайзер, 2019: 180).

Досліджуючи проблему морального виховання зростаючої особистості, I. Бех встановив, що основою моральної самосвідомості є моральна рефлексія, яка інтенсивно розвивається в підлітковому віці. Моральна рефлексія - здатність особистості осмислювати свої потреби, бажання, наслідки своїх вчинків для самої себе та інших людей, вміння узгоджувати цілі власної поведінки із засобами їх досягнення (Бех, 2012).

Як зазначав П. Якобсон, моральна рефлексія - це уміння особистості передбачати наслідки власних вчинків як для інших людей, так і для себе, уміння визначати віддалені та найближчі цілі й зіставляти їх із наявними засобами реалізації (Якобсон, 1958).

Що стосується емоційно-ціннісної складової моральної самосвідомості, то сюди належать моральні цінності та моральні почуття.

У своїх дослідженнях Г. Васянович стверджував, що моральна самосвідомість належить до моральної свідомості особистості, а також є їі особливою формою, ядро якої - вона сама та людина як її носій. Науковець виокремив структурні компоненти моральної самосвідомості як історичного, динамічного утворення: усвідомлення морального Я, мислення, пам'ять (сенсорна, довготривала, рухова, короткотривала, словесно-логічна, образна, емоційна) (Васянович, 2003).

Нам близьким є розуміння того, що формою моральної самосвідомості є моральні почуття (чесність, справедливість, честь тощо), вчений стверджував, що свідомість спрямована на зовнішній світ, а самосвідомість - на внутрішній світ особистості (Васянович, 2003). 
Утворення в особистості моральних почуттів, як зазначали О. Сухомлинська та А. Титаренко, вказує на те, що об'єктивно ціннісне стало для неї суб'єктивно значущим і перетворилось на частину її самосвідомості. Моральні почуття віддзеркалюють ставлення людини до різних сторін суспільного життя, визначають особливості нормативноціннісних взаємин з іншими людьми (почуття любові, ревнощів, ненависті, заздрості, довіри, чесності), а також відображають ставлення до себе (почуття гордості, честі) й до своїх моральних поразок (почуття звинувачення, сорому, каяття) (Сухомлинська, 2002; Титаренко, 1974).

У структурі моральної самосвідомості поведінковий компонент представлений моральною саморегуляцією. Ми погоджуємося із твердженням І. Булах, що моральна саморегуляція є джерелом творення особистості, $є$ тим механізмом, який внутрішньо спонукає особистість керувати власними діями та поведінкою згідно прийнятих у певному суспільстві норм (Булах, 2016).

Основним конструктом моральної саморегуляції $\epsilon$ самоконтроль, який $\epsilon$ обов'язковою умовою адекватного психічного відображення особистістю свого внутрішього світу та навколишньої дійсності. Згідно позиції М. Боришевського, перевірка ступеня збігу між моральними нормами, ідеалами, цінностями і цілями, мотивами реалізованого морального вчинку $\epsilon$ центральною функцією самоконтролю. Завдяки самоконтролю особистість може оцінювати мотиви, що передують моральному вчинку. В ситуації невідповідності у свідомості між моральними мотивами та засобами досягнення цілей конкретних моральних вчинків запускаються механізми корекції, які гальмують, стримують асоціальні дії й повертають їх у нормативне русло. Як зазначав учений, моральна саморегуляція поведінки має певні особливості, а саме: здатність до вибору (добро або зло), моральний вчинок, який є основою моральної поведінки (Боришевський, 1985).

Специфічним проявом морального вибору, на думку А. Титаренко, є моральний конфлікт, суть якого полягає в тому, що людина має зробити вибір між моральною цінністю та антицінністю на перевагу однієї і на основі цього протиріччя зреалізувати свою мету (Титаренко, 1974).

Ми погоджуємося 3 позицією С. Якобсона, що моральний вибір передбачає наявність двох полярних еталонів, адекватне ставлення до цих еталонів, зіставлення 3 цими еталонами особистості в цілому, зіставлення себе і власних вчинків 3 еталонами належного, що реалізується самим суб'єктом (Якобсон, 1981).

Дещо іншу структуру моральної самосвідомості пропонує А. Малихін: 1) когнітивний компонент: моральні уявлення, моральні поняття, моральні знання; 2) світоглядний компонент: моральні переконання, ціннісні орієнтації, інтереси; 3) поведінковий компонент: моральний мотив, моральні стосунки; 4) емоційний компонент: моральні почуття. На думку дослідника, групування структурних компонентів моральної самосвідомості таким чином відповідає основним проявам активності особистості в певній діяльності (пізнавальній, трудовій, моральній, під час спілкування). Система понять утворює необхідні моральні знання, які в процесі суспільно корисної діяльності й спілкування набувають суспільного та особистісного значення (Малихін, 2000). А. Реан виділяв наступні структурні компоненти моральної самосвідомості, що «знаходяться в нерозривній єдності трьох сторін: когнітивна (самопізнання), емоційна (ставлення до себе) і регулятивна, інтегральним продуктом яких виступає образ «Я» (Реан, 2003).

Таким чином, аналізуючи праці провідних науковців (Реан, 2003; Кон, 1984; Чеснокова, 1997; Столін, 1983), можна зробити висновок, що в більшості вони виділяють трьохкомпонентну структуру моральної самосвідомості, але при цьому дотримуються неоднозначної термінології щодо розуміння «наповненості» цих компонентів. Ними виділено афективний, емоційний, когнітивний, поведінковий i регулятивний аспекти 
моральної самосвідомості. При цьому з розумінням когнітивного компонента суттєвих розбіжностей не виникає.

Відмінності у трактуванні та сутності спостерігаються в афективному й емоційному компонентах. Зокрема, А. Реан, І. Чеснокова і В. Столін виділяли емоційний компонент, a I. Кон - афективний; під яким одні розуміють емоційно-ціннісне відношення до себе, а інші - позитивні або негативні почуття до об'єкта. Аналогічно з розумінням поведінкового і регулятивного компонента, де І. Кон виділяв поведінковий компонент «готовність до певного образу дій відносно об'єкта», а А. Реан, І. Чеснокова, В. Столін регулятивний; тобто, самоврядування, саморегуляція своєї поведінки (Кон, 1984; Реан, 2003; Столін, 1983; Чеснокова, 1997).

Таким чином, структура моральної самосвідомості зводиться до трьохкомпонентної будови і включає афективний, когнітивний, поведінковий компоненти.

\section{Висновки}

Отже, моральна самосвідомість - це така специфічна форма моральної свідомості, предметом якої виступає вона сама, а також особистість - іiі носій. Основними функціями моральної самосвідомості є осмислення, контролювання, санкціонування та критичний перегляд моральних настанов людської суб'єктивності. Існує багато теорій щодо змістового наповнення поняття «моральна самосвідомість». Більшість науковців виділяють трьохкомпонентну структуру моральної самосвідомості: когнітивний, афективний, поведінковий компоненти.

Проведене дослідження не вичерпує всіх аспектів порушеної багатогранної проблеми розвитку моральної самосвідомості особистості. Перспективу подальших наукових розвідок вбачаємо в емпіричному дослідженні механізмів розвитку моральної самосвідомості на певному етапі онтогенезу.

\section{Література}

1. Алексєєва, Ю.А. (2006). Становлення моральної самосвідомості підлітків у процесі психологічного консультування. (Дис. канд. психол. наук). Київ.

2. Бех, І.Д. (2012). Особистість у просторі духовного розвитку. Київ : Академвидав.

3. Бондаревська, О. (2007). Формування моральної свідомості особистості. Людина і світ, 3, 40-43.

4. Боришевський, М.Й. (1985). Розвиток морального саморегулювання поведінки учнів. Київ : Радянська школа.

5. Братусь, Б.С. (1994). Психология. Нравственность. Культура. Москва : Роспедагентство.

6. Булах, І.С. (2016). Психологія особистісного зростання підлітків: реалї та перспективи. Вінниця : ТОВ «Нілан-ЛТД».

7. Васянович, Г., Онищенко, В., \& Руденко, Л. (2003). Концептуальні засади моральнодуховної та етико-психологічної підготовки фахівців у системі професійно-технічної освіти. Педагогіка і психологія професійної освіти, 3, 11-19.

8. Зимянський, А.Р. (2009). Генезис форм прояву моральної самосвідомості підлітка. Проблеми загальної та педагогічної психології, 12(5), 129-135.

9. Клочек, Л.В. (2009). Суб'єктність і самосвідомість особистості в юнацькому віці. Науковий часопис НПУ імені М. П. Драгоманова. Серія 12. Психологічні науки, 23(47), 135-142.

10. Кон, И.С. (1984). В поисках себя. Личность и ее самосознание. Москва : Политиздат.

11. Малихін, А. (2000). Найкращий оберіг моральності. Рідна школа, 7, 57-64.

12. Павелків, Р.В. (2005). Розвиток моральної свідомості та самосвідомості в молодшому шкільному віці. (Дис. д-ра психол. наук). Рівне.

13. Реан, А.А. (2003). Психология подростка. Санкт-Петербург : Прайм - ЕВРОЗНАК. 
14. Савчин, М.В. (2005). Психологічний аналіз проблеми моральної свідомості та самосвідомості особистості. Педагогіка і психологія професійної освіти, 4, 115-131.

15. Синявський, В.В., \& Сергєєнкова, О.П. (2007). Психологічний словник. Київ : Науковий світ.

16. Степанов, О.М. (2006). Психологічна енцииклопедія. Київ : Академвидав.

17. Столин, В.В. (1983). Самосознание личности. Москва : Изд-во МГУ.

18. Сухомлинська, О. (2002). Концептуальні засади формування духовності особистості на основі християнських моральних якостей. Шлях освіти, 4, 3-18.

19. Титаренко, А.И. (1974). Структура нравственного сознания. Москва : Мысль.

20. Флоренская, Т.А. (2001). Диалог в практической психологии: Наука о душе. Москва : Гуманит. изд. центр ВЛАДОС.

21. Чеснокова, И.И. (1997). Проблемы самосознания в психологии. Москва : Наука.

22. Якобсон, П.М. (1958). Психология чувств. Москва : Изд-во АПН.

23. Якобсон, С.Г. (1981). Становление психологических механизмов этической регуляции поведения. Л.И. Анцыферова (Ред.), Психология формирования и развития личности (с. 320-337). Москва : Наука.

24. Althof, W., \& Berkowitz, M. (2006). Moral education and character education: Their relationship and roles in citizenship education. Journal of Moral Education, 35(Dec), 495518. doi: $10.1080 / 03057240601012204$

25. Han, H. (2014). Analyzing theoretical frameworks of moral education through Lakatosos philosophy of science. Journal of Moral Education, 43(1, Mar), 32-53. doi: $10.1080 / 03057240.2014 .893422$

26. Krettenauer, T. (2020). Moral identity as a goal of moral action: A Self-Determination Theory perspective. Journal of Moral Education, Jan. doi: 10.1080/03057240.2019.1698414

27. Ramos, A., Griffin, A., Neiderhiser, J., \& Reiss, D. (2019). Did I inherit my moral compass? Examining socialization and evocative mechanisms for virtuous character development. Behavior Genetics, 49(2), 175-186. doi:10.1007/s10519-018-09945-4

28. Walker, L.J. (2019). The character of character: The 2019 Kohlberg Memorial Lecture. Journal of Moral Education, 48(3), 275-279. doi: 10.1080/03057240.2019.1698415

\section{References}

1. Alieksieieva, Yu.A. (2006). Stanovlennia moralnoii samosvidomosti pidlitkiv u protsesi psykholohichnoho konsultuvannia [The formation of the moral selfconsciousness of teenagers in the process of psychological konsultansy]. Candidate's thesis. Kyiv [in Ukrainian].

2. Bekh, I.D. (2012). Osobystist u prostori dukhovnoho rozvytku [Personality in the space of spiritual development]. Kyiv : Akademvydav [in Ukrainian].

3. Bondarevska, Ye.V. (2007). Formuvannia moralnoii svidomosti osobystosti [The formation of personality moral consciousness]. Liudyna $i$ svit - A human and the world, 3, 40-43 [in Ukrainian].

4. Boryshevskyi, M.Y. (1985). Rozvytok moralnoho samorehuliuvannia povedinky uchniv [The development of students' behaviour selfregulation]. Kyiv : Radyans'ka shkola [in Ukrainian].

5. Bratus, B.S. (1994). Psikhologija. Nravstvennost. Kultura [Psychology. Morality. Culture]. Moscow : Rospedagenstvo [in Russian].

6. Bulakh, I.S. (2016). Psykholohiia osobystisnoho zrostannia pidlitkiv: realiii ta perspektyvy [The psychology of teenagers' personality: realias and perspectives]. Vinnytsia : TOV «Nilan-LTD» [in Ukrainian].

7. Vasianovych, H., Onyschenko, V., \& Rudenko, L. (2003). Kontseptualni zasady moralnodykhovnoii ta etyko-psykholohichnoii pidhotovky fahivtsiv u systemi profesiino-tehnichnoi osvity [Conceptual fundamentals of moral, ethical and psychological specialists' training in a 
professional and technical educational system]. Pedagogica i psykholohiia profesiinoi osvity - Pedagogy and Psychology of professional education, 3, 11-19 [in Ukrainian].

8. Zymianskyi, A.R. (2009). Henezis form proiavu moralnoii samosvidomosti pidlitka [The origin of teenager's moral selfconsciousness]. Problemy zahalnoii ta pedahohichnoi psykholohii-General and Pedagogical Psychology problems, 12(5), 129-135 [in Ukrainian].

9. Klochek, L.V. (2009). Subiektnist i samosvidomist osobystosti v yunatskomu vitsi [Personality and identity of a young person]. Naukovyi chasopys NPU imeni M.P. Drahomanova. Seriia 12. Psykholohichni nauky - Scientific journal of Dragomanov NPU. Series 12. Psychological Sciences, 23(47), 135-142 [in Ukrainian].

10. Kon, I.S. (1984). V poiskah sebja. Lichnost' $i$ ee samosoznanie. [In quest of myself. Personality and its selfconsciousness]. Moscow : Politizdat [in Russian].

11. Malyhin, A. (2000). Naikraschyi oberih moralnosti [The best moral averter]. Ridna shkolaA native school, 7, 57-64 [in Ukrainian].

12. Pavelkiv, R.V. (2005). Rozvytok moralnoi svidomosti ta samosvidomosti v molodshomu shkilnomu vitsi [The development of moral consciousness and selfconsciousness in primary school age]. Candidate's thesis. Rivne : RDHU [in Ukrainian].

13. Rean, A.A. (2003). Psikhologija podrostka [Adolescent Psychology]. Sankt-Peterburg : Prajm - EVROZNAK [in Russian].

14. Savchyn, M.V. (2005). Psykholohichnyi analis problem moralnoi svidomosti ta samosvidomosti osobystosti [A psychological analysis of moral consciousness and selfconsciousness problem]. Pedahohika i psykholohiia profesiinoii osvity - Pedagogy and Psychology of professional education, 4, 15-131 [in Ukrainian].

15. Syniavskyi, V.V., \& Sierhieienkova, O.P. (2007). Psykholohichnyi slovnyk [Dictionary of Psychology]. Kyiv : Naukovyi svit [in Ukrainian].

16. Stepanov, O.M. (2006). Psykholohichna entsyklopediia [Psychology Encyclopedia]. Kyiv : Akademvydav [in Ukrainian].

17. Stolin, V.V. (1983). Samosoznanije lichnosti [Personality consciousness]. Moscow : Izd-vo MGU [in Russian].

18. Sukhomlynska, O. (2002). Kontseptualni zasady formuvannia dukhovnosti osobystosti na osnovi khrystyianskykh moralnykh yakostei [Conceptual principles of formation of personality spirituality on the basis of Christian moral qualities]. Shliakh osvity - Path of Education, 4, 3-18 [in Ukrainian].

19. Titarenko, A.I. (1974). Struktura nravstvennogo soznanija [The structure of moral consciousness]. Moscow : Mysl' [in Russian].

20. Florenskaja, T.A. (2001). Dialog v prakticheskoj psikhologiji: Nauka o dushe [Dialogue in Practical Psychology: The science about soul]. Moscow : Gumanit. izdv. tsentr VLADOS [in Russian].

21. Chesnokova, I.I. (1997). Problemy samosoznanija v psikhologiji [The problems of selfconsciousness in Psychology]. Moscow : Nauka [in Russian].

22. Yakobson, P.S. (1958). Psikhologiia chuvstv [Psychology of feelings]. Moscow : Izd-vo APN [in Russian].

23. Yakobson, S.G. (1981). Stanovlenie psihologicheskih mehanizmov jeticheskoj reguljacii povedenija [The formation of psychological ethical behavioural regulation mechanisms]. In L.I. Ancyferova (Ed.), Psihologija formirovanija i razvitija lichnosti - Psychology of personality formation and development (pp. 320-337). Moscow : Nauka [in Russian].

24. Althof, W., \& Berkowitz, M. (2006). Moral education and character education: Their relationship and roles in citizenship education. Journal of Moral Education, 35 (Dec), 495518. doi: $10.1080 / 03057240601012204$

25. Han, H. (2014). Analyzing theoretical frameworks of moral education through Lakatosos philosophy of science. Journal of Moral Education, 43(1, Mar), 32-53. doi: $\underline{10.1080 / 03057240.2014 .893422}$ 
26. Krettenauer, T. (2020). Moral identity as a goal of moral action: A Self-Determination Theory perspective. Journal of Moral Education, Jan. doi: 10.1080/03057240.2019.1698414

27. Ramos, A., Griffin, A., Neiderhiser, J., \& Reiss, D. (2019). Did I inherit my moral compass? Examining socialization and evocative mechanisms for virtuous character development. Behavior Genetics, 49(2), 175-186. doi:10.1007/s10519-018-09945-4

28. Walker, L.J. (2020). The character of character: The 2019 Kohlberg Memorial Lecture. Journal of Moral Education. doi: 10.1080/03057240.2019.1698415

\title{
THE STRUCTURE OF PERSONALITY MORAL SELF-CONSCIOUSNESS Liudmyla Kotlova \\ PhD in Psychology, Associate Professor of the Department of Developmental Psychology and Consultancy \\ Ivan Franko Zhytomyr State University 406 Velyka Berdychivska Str., Zhytomyr, Ukraine, 10008 \\ kotlova.1o@i.ua, https://orcid.org/0000-0003-2994-6724
}

\begin{abstract}
The article deals with the theoretical analysis of approaches to the understanding of personality moral self-consciousness. It is focused on singling out theoretical psychological peculiarities, a structure and mechanisms of the personality moral self-consciousness development. The main objectives are a psychological analysis and generalization of moral consciousness formation peculiarities which are based on it.

Moral self-consciousness is defined as a specific form of moral consciousness, selfconsciousness, one's own moral values, attitudes, qualities, potential opportunities, actions and their motives, consequences, one's own behavior regulation and moral self-improvement.

There are two levels of moral self-consciousness. The other person's «I», its qualities evaluation are compared at the first level, and then these qualities are transferred to you. At the second level, there is a correlation of self-knowledge in the process of auto communication, that is to say, within the limits of «I and I». A person has already operated with formed knowledge of himself/herself. At this level, the person brings into correlation his/her behavior with the motivation he/she realizes.

Moral self-consciousness can have a three-component structure which includes affective (emotional), cognitive, behavioral (regulatory) components, or a four-component structure (cognitive, worldview, behavioral, emotional components). The main characteristics of the moral consciousness cognitive component are moral knowledge, beliefs and moral reflection. The emotional value component of moral consciousness is represented by moral values and moral feelings. The behavioral component is presented by moral self-regulation.

Moral self-consciousness is not only an understanding of certain problems and life circumstances in terms of moral values acknowledged by the person, it is his/her own self-esteem, attempt to understand the justice and validity of the moral principles which he/she is guided by.
\end{abstract}

Keywords: moral self-consciousness, affective component, emotional component, cognitive component, behavioral component, worldview component. 